\title{
AGRICULTURAL ENTERPRISES AND ECONOMIC GROWTH: A REGIONAL ANALYSIS IN THE REPUBLIC OF SERBIA
}

\author{
Miloš Dimitrijevićl, Stefan Vržina ${ }^{2}$, Miljan Leković3 \\ *Corresponding authorE-mail: mdimitrijevic@kg.ac.rs
}

\begin{abstract}
A R T I C LE IN F O
A B S T R A C T

Review Article

Received: 14 May 2020

Accepted: 25 May 2020

Since agriculture is the highly important economic doi:10.5937/ekoPolj2002585D

UDC 338.1:631.1(497.11)

Keywords:

Agricultural enterprises, economic growth, agriculture, agribusiness, regional economic activity activity in the Republic of Serbia, it is necessary to create an environment in which competitive agricultural enterprises will develop. However, regions in the Republic of Serbia considerably differ regarding the intensity of agricultural activity. This paper examines the impact of agricultural enterprises on the region's contribution to the gross domestic product (GDP) of the country in the period between 2010 and 2018. Activity of agricultural enterprises was observed using number of agricultural enterprises, number of employees in them, their turnover and gross value added. Random-Effects GLS regression showed that regions with higher agricultural activity JEL: O13, Q12, Q13, R11 contribute to the lesser extent to the GDP of the country. Research results are robust to changing sampling period and lagging independent variables. In this regard, several proposals have been recommended.
\end{abstract}

(C) 2020 EA. All rights reserved.

\section{Introduction}

The performance of agricultural enterprises is determined by their ability to adapt to volatile market conditions and integrate into the economic system. As agriculture is the important industry in the Republic of Serbia, it is necessary to emphasize the significance of agricultural enterprises and their participation in the economic growth of the Republic of Serbia.

1 Miloš Dimitrijević, Ms.C, Research Trainee, University of Kragujevac - Faculty of Economics, Liceja Kneževine Srbije 3, 34000 Kragujevac, Serbia. Phone: +381 34303 562. E-mail: mdimitrijevic@kg.ac.rs. ORCID ID (https://orcid.org/0000-0001-9253-8876)

2 Stefan Vržina, Ms.C, Research Trainee, University of Kragujevac - Faculty of Economics, Liceja Kneževine Srbije 3, 34000 Kragujevac, Serbia. Phone: +381 34303 562. E-mail: stefan.vrzina@kg.ac.rs. ORCID ID (https://orcid.org/0000-0001-8372-591X)

3 Miljan Leković, Ph.D., Assistant Professor, University of Kragujevac, Faculty of Hotel Management and Tourism in Vrnjačka Banja, Vojvođanska 5A, 36210 Vrnjačka Banja, Serbia. Phone: +381 6435823 04. E-mail: m.lekovic@kg.ac.rs. ORCID ID (https://orcid. org/0000-0002-4952-3991)

http://ea.bg.ac.rs 
The role of agricultural enterprises in the development of the entire agribusiness sector is crucial. Agribusiness may be defined as the sum of all operations covering the production and distribution of agricultural supplies, production operations on the farm, storage, processing and distribution of agricultural goods and objects made from them (King et al., 2010, p. 554). In other words, agribusiness consists of the pre-farm activities (production of industrial inputs for the agrarian sector), primary agriculture (production of agricultural raw materials for food processing and production) and postfarm activities (processing, sales and consumption of final food products) (Milanović et al., 2013, p. 299). The coordination and integration of such activities is important, because only in these conditions an adequate environment for the development of agricultural enterprises may be created. Challenges that alter management efficiency and modern decision-making are crucial to the agrarian sector and, wider, to the agribusiness (Lowe \& Preckel, 2004).

Agribusiness is a particularly interesting field for small and medium-sized enterprises (SMEs), as it is a very broad area covering the production and processing of agricultural and food products, as well as numerous inputs for agricultural production (Maletić \& Ćeranić, 2010). SMEs are usually family businesses. There are one or more owners in these companies, mainly family members, and a few full-time employees.

The structure of agricultural enterprises in the Republic of Serbia is dominated by SMEs that represent the main source of increasing employment, export and welfare of the country. In Serbian agricultural sector, the largest percentage of enterprises regards micro and small enterprises, followed by medium and little portion of large enterprises. Strong development and competitiveness of the SMEs may be one of the guides for economic development of the Republic of Serbia, similar to those in developed countries. In fact, SMEs represent a basis of economic development, both for developed and developing countries (Bošković \& Kostadinović, 2011), and have become one of the most important economic operators in the agrarian sector, thus replacing the dominance of cooperatives and large agricultural enterprises (Pantić, 2015).

Cooperatives, SMEs and other forms of business associations should support the economic development, since small family households are the largest employers in the world and provide more than $80 \%$ of the value of the world food (Aničić et al., 2019). In addition, "SMEs networks are becoming increasingly important for the innovation activities of agri-food firms" (Batterink et al., 2010, p.68) as innovative products and market research have become some of the main tasks of the agri-food system (Avermaete et al., 2003; Drăgoi et al., 2018; Knudson et al., 2004).

In the context of economic growth (Andrei et al., 2017), the attention should not be only paid to the SMEs, but also to the large agricultural companies. In this regard, the position of large agricultural companies in the Republic of Serbia does not significantly differ from the position of SMEs. For instance, Tomašević et al. (2019) find that large agricultural companies report higher profitability than agricultural SMEs, but this difference is not statistically significant. 
Many agricultural companies, in particular large companies, experienced severe financial difficulties after bad privatization processes and global financial crisis (Bubić $\&$ Hajnrih, 2012). Such circumstances resulted in declining profitability and efficiency of agricultural companies and also in the problems to service their liabilities.

"Agriculture is the highly important economic activity in the Republic of Serbia" (Petrović \& Vuković, 2016, p.1433). However, "the Serbian agriculture is largely characterized by family farms with inadequate age and educational structure and low entrepreneurship levels" (Sedlak et al., 2016, p.1230). At most of these farms, the production is at a low technological level, which directly results in low productivity levels. Therefore, it is important to create an adequate environment and access to resources for their development, given that SMEs in particular have limited access to financing sources and higher costs of them than large enterprises. "Developing the capital market and providing better access to agribusiness loans, including new forms of lending, is one of the preconditions for the development of micro and SMEs" (Sedlak et al., 2016, p.1231).

It is interesting to analyze the contribution of agricultural enterprises to the gross domestic product (GDP) on the regional level, assuming the considerable crossregional differences in intensity of agricultural activity in the Republic of Serbia. For instance, two most developed regions in the Republic of Serbia - Belgrade and Vojvodina (Mijačić \& Paunović, 2011) completely differ regarding the agricultural activity. Belgrade has the lowest, while Vojvodina has the highest agricultural activity in the Republic of Serbia. In addition, most of the SMEs in agribusiness are located in Vojvodina as a region with favorable conditions and long tradition in entrepreneurship (Maletić, 2014).

The analysis that ranked the municipalities according to their SMEs development pointed out the unequal regional development regarding agricultural SMEs. In the Vojvodina, there are the most registered agricultural SMEs, followed by Central Serbia and Southern and Eastern Serbia. The most developed ones are those from Vojvodina and some Belgrade municipalities, unlike those from Central Serbia, and especially from Southern and Eastern Serbia (Popović, 2009).

Therefore, regional specificities are the starting point in planning the development of agrarian sector, agribusinesses and the economy as a whole. This should overcome the problems of underdeveloped and rural areas, unbalanced regional development and better exploitation of natural resources.

For the further development of agricultural sector in the Republic of Serbia, a statesupported stimulating environment is needed (Ristić, 2013). In order to strengthen the development of agriculture and rural areas, the Strategy for the Agriculture and Rural Development of the Republic of Serbia 2014-2024 defines three most important reform segments (Aničić et al., 2016, p. 176): 
1. "Agricultural policy reform;

2. Legislation adoption and complete application;

3. Institutional reforms".

The very important feature of the agricultural and overall economic development is entrepreneurship development. Even in agriculture, in the Republic of Serbia there are great possibilities for entrepreneurship development in agribusiness. On the other hand, agricultural companies have mainly shared the destiny of the rest of the economy in the Republic of Serbia at the beginning of the $21^{\text {st }}$ century: insufficient GDP growth and stagnation, unfavorable macroeconomic environment, high unemployment rate, etc.

The subject of the paper are agricultural enterprises in the Republic of Serbia. Researching this issue, Vržina \& Dimitrijević (2020) find that "agricultural enterprises in the Republic of Serbia report only moderate profitability rates" (p. 8). These companies usually have highly concentrated ownership and relatively low indebtedness due to difficult access to the debt market. In addition, many agricultural companies have problems with disparity between assets maturity and debt maturity. On the other hand, Aničić et al. (2016) argue that agriculture can contribute to the "economic development, increase GDP and become the framework of the total economic stability" (p. 178).

The objective of the paper is to examine the impact of activity of agricultural enterprises on the economic growth. Respecting cross-regional differences in the agricultural activity, the analysis in the paper is conducted on the regional level. Therefore, the paper examines the impact of activity of agricultural companies on the region's contribution to the GDP.

In the line with defined research subject and objective, the following null and alternative research hypotheses will be tested in the paper:

$\mathrm{H}_{0}$ : Activity of agricultural enterprises does not have statistically significant impact on region's contribution to the GDP.

$\mathrm{H}_{1}$ : Activity of agricultural enterprises has statistically significant impact on region's contribution to the GDP.

After the introduction, the materials and methods of the paper are presented. The following section of the paper presents research results, including also the robustness checks and research results discussion. Final section of the paper concludes and provides recommendations for future research.

\section{Materials and methods}

In the paper was examined how the activity of agricultural enterprises affects the contribution of the region to the GDP of the Republic of Serbia. Therefore, NUTS (Nomenclature of Units for Territorial Statistics) 2 regional level was used in the paper. In this regard, five regions in the Republic of Serbia exist (Belgrade, Vojvodina, 
Šumadija and Western Serbia, Southern and Eastern Serbia, and Kosovo and Metohija). The region of Kosovo and Metohija was excluded from the analysis due to data unavailability. The analyzed period is from 2010 to 2018, as NUTS 2 classification was introduced in 2010. Covering four regions across nine-year period, the sample represented the balanced panel data of 36 observations.

Activity of agricultural enterprises was measured by number of agricultural enterprises (A_ENT), number of employees in them (A_EMPL), turnover (A_TURN) and gross value added (A_GVA) of agricultural enterprises. Necessary data were retrieved from the Statistical Office of the Republic of Serbia (2010-2018). Data contains the numbers from annual statutory financial statements for enterprises and cooperatives in the Republic of Serbia.

Contribution of the region to the GDP of the country is measured by the relation between GDP of the region and GDP of the country (GDP_C). The impact of the agricultural enterprises on region's contribution to the GDP was controlled for the impact of some macroeconomic and demographic variables: share of region's unemployment (UNEMPL), export (EXPORT) and population (POPUL) in the country's total. These data were also retrieved from the Statistical Office of the Republic of Serbia. Table 1 presents definition of employed variables.

Table 1. Definition of variables

\begin{tabular}{|c|l|}
\hline Label & \multicolumn{1}{|c|}{ Definition } \\
\hline Dependent variable \\
\hline GDP_C & GDP of the region / GDP of the country \\
\hline Agricultural independent variables \\
\hline A_ENT & Number of agricultural companies in the region / Number of companies in the region \\
\hline A_EMPL & $\begin{array}{l}\text { Number of employees in agricultural companies in the region / Number of employees in } \\
\text { companies in the region }\end{array}$ \\
\hline A_TURN & Turnover of agricultural companies in the region / Turnover of companies in the region \\
\hline A_GVA & $\begin{array}{l}\text { Gross value added of agricultural companies in the region / Gross value added of } \\
\text { companies in the region }\end{array}$ \\
\hline Control variables \\
\hline UNEMPL & $\begin{array}{l}\text { Number of unemployed people in the region / Number of unemployed people in the } \\
\text { country }\end{array}$ \\
\hline EXPORT & Exports of the region / Exports of the country \\
\hline POPUL & Poppulation of the region / Population of the country (as of 2011 Census of population) \\
\hline
\end{tabular}

Source: Authors' definition

Considering employed variables, it is possible to formulate the following linear regression model:

$$
G D P C_{i, t}=\alpha+\beta_{i} A G R I C U L T U R E_{i, t}+\beta_{2} U N E M P L_{i, t}+\beta_{3} \text { EXPORT }_{i, t}+\beta_{4} P O P U L_{i, t}+\varepsilon_{i, t}
$$

where AGRICULTURE refers to A_ENT, A_EMPL, A_TURN and A_GVA of region $i$ in year $t$. 
A random-effects General Least Squares (GLS) regression was employed in the paper, as Breusch-Pagan LM test showed that this model should be preferred over Ordinary Least Squares (OLS) estimates. In addition, fixed effects regression was not applied due to near singular matrix problem, as population variable is invariant over time. The statistical package Stata 14 was used for the analysis.

In order to test the robustness of the results, changes of the initial research model were also conducted in the paper. There were conducted following robustness checks:

- change of the sampling period (2014-2018 instead of 2010-2018) to cover only the period under the Strategy for Agriculture and Rural Development 2014-2024;

- lagging the independent variables employed in the model.

\section{Research Results}

The following part of the paper presents research results including descriptive statistics, univariate analysis, regression analysis, robustness checks and discussion of the results.

\section{Descriptive Statistics}

Table 2 presents descriptive statistics for all variables used in the analysis. Region's contribution to the GDP of the country (GDP_C) was the variable with the highest deviation from the arithmetic mean. This finding implies significant regional differences in the Republic of Serbia. In each year, the Belgrade region had the highest GDP_C value, followed by Vojvodina, Šumadija and Western Serbia, and Southern and Eastern Serbia. The highest GDP_C value regards Belgrade region in 2018, while the lowest value regards Southern and Eastern Serbia in 2016.

Agricultural independent variables (A_ENT, A_EMPL, A_TURN and A_GVA) also exhibited important cross-regional differences. Vojvodina is the region with the highest agricultural activity, as maximum values of each agricultural independent variable regard this region. On the other hand, minimum values of these variables regard Belgrade region, except of the A_EMPL that regards Šmadija and Western Serbia region. In addition, Sumadija and Western Serbia region, and Southern and Eastern Serbia region had nearly same values of agricultural independent variables across the observed period.

Table 2. Descriptive Statistics

\begin{tabular}{|c|r|c|c|r|r|}
\hline $\mathbf{n}=\mathbf{3 6}$ & $\begin{array}{c}\text { Arithmetic } \\
\text { mean }\end{array}$ & Median & Minimum & Maximum & $\begin{array}{c}\text { Standard } \\
\text { deviation }\end{array}$ \\
\hline \multicolumn{7}{|c|}{ Dependent variable } \\
\hline GDP_C (\%) & 24.98 & 22.90 & 13.63 & 41.35 & 9.89 \\
\hline \multicolumn{7}{|c|}{ Agricultural independent variables } \\
\hline A_ENT (\%) & 4.34 & 4.50 & 0.82 & 7.63 & 2.36 \\
\hline A_EMPL (\%) & 3.41 & 1.83 & 1.15 & 9.66 & 3.05 \\
\hline A_TURN (\%) & 3.74 & 2.41 & 0.71 & 10.49 & 3.50 \\
\hline
\end{tabular}




\begin{tabular}{|c|r|r|r|r|r|}
\hline $\mathbf{n}=\mathbf{3 6}$ & $\begin{array}{c}\text { Arithmetic } \\
\text { mean }\end{array}$ & Median & Minimum & Maximum & $\begin{array}{c}\text { Standard } \\
\text { deviation }\end{array}$ \\
\hline A_GVA (\%) & 2.99 & 1.38 & 0.79 & 9.27 & 3.12 \\
\hline \multicolumn{7}{|c|}{ Control variables } \\
\hline UNEMPL (\%) & 25.00 & 25.73 & 17.19 & 31.14 & 3.58 \\
\hline EXPORT (\%) & 24.99 & 24.67 & 12.82 & 37.20 & 7.20 \\
\hline POPUL (\%) & 25.00 & 24.99 & 21.76 & 28.27 & 2.70 \\
\hline
\end{tabular}

Source: Authors' calculation

Regarding control independent variables, the lowest value of UNEMPL was reported in Belgrade in 2010, while the highest value was reported in Šumadija and Western Serbia in 2018. In fact, the Belgrade region contributed the least to the country's unemployment in each year. On the other hand, the Vojvodina region, on the average, contributed the most to the export of the country, while Southern and Eastern Serbia contributed the least. The largest region in terms of population was Šumadija and Western Serbia, while Southern and Eastern Serbia had the lowest population.

\section{Univariate Analysis}

Table 3 presents Pearson's correlation coefficients and their statistical significance. It may be concluded that only one agricultural independent variable (A_ENT) had a significant correlation with our dependent variable. On the other hand, there was significant high and positive correlation between all the agricultural independent variables. In general, control variables appeared to have significant correlation with agricultural independent variables, with the highest correlation recorded between $\mathrm{A}_{-}$ GVA and EXPORT.

Table 3. Pearson's Correlation Matrix

\begin{tabular}{|c|r|r|r|r|r|r|r|r|}
\hline $\mathrm{n}=36$ & GDP_C & A_ENT & A_EMPL & A_TURN & A_GVA & UNEMPL & EXPORT & POPUL \\
\hline GDP_C & 1.00 & & & & & & & \\
\hline A_ENT & $* * *-0.53$ & 1.00 & & & & & & \\
\hline A_EMPL & 0.10 & $* * * 0.75$ & 1.00 & & & & & \\
\hline A_TURN & -0.08 & $* * * 0.87$ & $* * * 0.97$ & 1.00 & & & & \\
\hline A_GVA & 0.07 & $* * * 0.78$ & $* * * 0.99$ & $* * * 0.99$ & 1.00 & & & \\
\hline UNEMPL & $* * *-0.47$ & $* * * 0.55$ & 0.22 & $* * 0.34$ & 0.25 & 1.00 & & \\
\hline EXPORT & $* * 0.37$ & $* * * 0.46$ & $* * * 0.74$ & $* * * 0.71$ & $* * * 0.75$ & 0.27 & 1.00 & \\
\hline POPUL & -0.08 & $* * * 0.53$ & $* * 0.39$ & $* * * 0.48$ & $* * 0.42$ & $* * * 0.66$ & $* * * 0.67$ & 1.00 \\
\hline
\end{tabular}

Note: $*, * *, * * *$ denotes statistical significance at the level of $10 \%, 5 \%$ and $1 \%$, respectively

\section{Regression Analysis}

Since the activity of agricultural enterprises was measured with four different variables, there were four regression models to be reported. Table 4 presents random-effects GLS regression estimates. Multicollinearity problems are not expected since Variance inflation factor is lower than 10 for each variable in each regression model. 
Table 4. Random-Effects GLS regression estimates

\begin{tabular}{|c|c|c|c|c|}
\hline & \multicolumn{4}{|c|}{ Dependent variable: GDP_C } \\
\hline & Model 1 & Model 2 & Model 3 & Model 4 \\
\hline Intercept & $\begin{array}{r}* * * 34.78 \\
(4.37) \\
\end{array}$ & $\begin{array}{r}* * 52.82 \\
(4.49) \\
\end{array}$ & $\begin{array}{r}* * * 45.38 \\
(4.16) \\
\end{array}$ & $\begin{array}{r}* * * 50.51 \\
(4.36) \\
\end{array}$ \\
\hline A_ENT & $\begin{array}{r}* *-3.13 \\
(-7.48) \\
\end{array}$ & & & \\
\hline A_EMPL & & $\begin{array}{r}* *-1.33 \\
(-2.21)\end{array}$ & & \\
\hline A_TURN & & & $\begin{array}{r}* * *-1.62 \\
(-3.56) \\
\end{array}$ & \\
\hline A_GVA & & & & $\begin{array}{r}* *-1.48 \\
(-2.53)\end{array}$ \\
\hline UNEMPL & $\begin{array}{l}*-0.57 \\
(-1.77) \\
\end{array}$ & $\begin{array}{r}* * *-1.29 \\
(-2.74) \\
\end{array}$ & $\begin{array}{r}* *-1.08 \\
(-2.49) \\
\end{array}$ & $\begin{array}{r}* * *-1.24 \\
(-2.68) \\
\end{array}$ \\
\hline EXPORT & $\begin{array}{r}* * * 1.17 \\
(7.50) \\
\end{array}$ & $\begin{array}{r}* * * 1.34 \\
(4.04) \\
\end{array}$ & $\begin{array}{r}* * * 1.45 \\
(5.26) \\
\end{array}$ & $\begin{array}{r}* * 1.39 \\
(4.31) \\
\end{array}$ \\
\hline POPUL & $\begin{array}{r}-0.45 \\
(-0.88) \\
\end{array}$ & $\begin{array}{r}-0.97 \\
(-1.18) \\
\end{array}$ & $\begin{array}{r}-0.94 \\
(-1.28) \\
\end{array}$ & $\begin{array}{r}-1.00 \\
(-1.24) \\
\end{array}$ \\
\hline Adjusted $\mathrm{R}^{2}$ & 0.82 & 0.56 & 0.64 & 0.58 \\
\hline Wald chi square & $* * * 140.05$ & $* * * 39.62$ & $* * * 54.86$ & $* * * 42.55$ \\
\hline Period & 2010-2018 & $2010-2018$ & 2010-2018 & $2010-2018$ \\
\hline Observations & 36 & 36 & 36 & 36 \\
\hline
\end{tabular}

Note: beta coefficients in front of parentheses, z-values in parentheses; *,**,*** denotes statistical significance at the level of $10 \%, 5 \%$ and $1 \%$, respectively

Multicollinearity problems are not expected since Variance inflation factor is lower than 10 for each variable in each regression model. Regression estimates suggest that agricultural enterprises had a negative and statistically significant impact on the region's contribution to the GDP of the country. In other words, regions with higher agricultural activity contributed to a lesser extent to the economic growth of the country, on the average. This conclusion holds regardless of the measure of the activity of agricultural enterprises. However, this impact was the strongest using the number of agricultural enterprises as a measure of agricultural activity. Therefore, the research results support the alternative hypothesis, thus rejecting the null hypothesis.

Among control independent variables, UNEMPL and EXPORT are the variables that had a significant impact in each regression model. Therefore, the regions with lower share in country's unemployment and higher share in country's export contributed more to the economic growth of the country.

\section{Robustness Checks}

First robustness check was conducted using shorter sampling period in order to cover only the period under the Strategy for Agriculture and Rural Development 2014-2024. Table 5 presents the regression estimates for the first robustness check. 
Table 5. Random-Effects GLS regression estimates for the period 2014-2018

\begin{tabular}{|c|c|c|c|c|}
\hline & \multicolumn{4}{|c|}{ Dependent variable: GDP_C } \\
\hline & Model 1 & Model 2 & Model 3 & Model 4 \\
\hline Intercept & $\begin{array}{r}* * 46.83 \\
(4.99) \\
\end{array}$ & $\begin{array}{r}* * * 66.23 \\
(4.41) \\
\end{array}$ & $\begin{array}{r}* * 57.46 \\
(4.36) \\
\end{array}$ & $\begin{array}{r}* * * 61.63 \\
(4.16) \\
\end{array}$ \\
\hline A_ENT & $\begin{array}{r}* * *-2.96 \\
(-6.97) \\
\end{array}$ & & & \\
\hline A_EMPL & & $\begin{array}{r}* * *-2.11 \\
(-2.91) \\
\end{array}$ & & \\
\hline A_TURN & & & $\begin{array}{r}* * *-1.95 \\
(-3.96) \\
\end{array}$ & \\
\hline A_GVA & & & & $\begin{array}{r}* * *-1.98 \\
(-3.01) \\
\end{array}$ \\
\hline UNEMPL & $\begin{array}{r}0.37 \\
(0.80) \\
\end{array}$ & $\begin{array}{r}0.71 \\
(0.95) \\
\end{array}$ & $\begin{array}{r}0.58 \\
(0.88) \\
\end{array}$ & $\begin{array}{r}0.77 \\
(1.04) \\
\end{array}$ \\
\hline EXPORT & $\begin{array}{r}* * * 1.75 \\
(7.77) \\
\end{array}$ & $\begin{array}{r}* * 2.50 \\
(5.59) \\
\end{array}$ & $\begin{array}{r}* * 2.42 \\
(6.66) \\
\end{array}$ & $\begin{array}{r}* * * 2.51 \\
(5.69) \\
\end{array}$ \\
\hline POPUL & $\begin{array}{r}* * *-2.48 \\
(-3.32) \\
\end{array}$ & $\begin{array}{r}* * *-4.59 \\
(-3.90) \\
\end{array}$ & $\begin{array}{r}* * *-4.02 \\
(-3.93) \\
\end{array}$ & $\begin{array}{r}* *-4.52 \\
(-3.89) \\
\end{array}$ \\
\hline Adjusted $\mathrm{R}^{2}$ & 0.89 & 0.70 & 0.77 & 0.70 \\
\hline Wald chi square & $* * * 118.89$ & $* * * 34.46$ & $* * * 49.61$ & $* * * 35.63$ \\
\hline Period & 2014-2018 & 2014-2018 & 2014-2018 & 2014-2018 \\
\hline Observations & 20 & 20 & 20 & 20 \\
\hline
\end{tabular}

Note: beta coefficients in front of parentheses, z-values in parentheses; *,**,*** denotes statistical significance at the level of $10 \%, 5 \%$ and $1 \%$, respectively

Regression estimates from the Table 5 suggest that the impact of the agricultural activity on the region's contribution to the GDP of the country is robust to the change of the sampling period. Using only the period under Strategy for the Agriculture and Rural Development 2014-2024, it may be concluded that the impact of agricultural activity on region's contribution to the GDP remained significantly negative. Robustness regression model employing A_ENT variable suggest that such negative impact was weaker after the implementation of the strategy, while regression models employing A_EMPL, A_TURN and A_GVA suggest the opposite.

An important feature of the macroeconomics is that some variables may affect each other with a time lag. Therefore, the second robustness check assumed lagging independent variables and using their first lag. Table 6 presents the regression estimates with lagged independent variables.

Regression estimates from the Table 6 confirm the initial research results, suggesting that agricultural activity also had a negative impact on region's contribution to the GDP with the one-year time lag. However, the impact of lagged independent variables is slightly weaker than the impact in the initial regression estimates. Therefore, it may be concluded that research results are robust to lagging the independent variables. 
Table 6. Random-Effects GLS regression estimates with lagged independent variables

\begin{tabular}{|c|c|c|c|c|}
\hline & \multicolumn{4}{|c|}{ Dependent variable: GDP_C } \\
\hline & Model 1 & Model 2 & Model 3 & Model 4 \\
\hline Intercept & $\begin{array}{r}* * * 37.13 \\
(4.12) \\
\end{array}$ & $\begin{array}{r}* * 55.69 \\
(4.37) \\
\end{array}$ & $\begin{array}{r}* * * 48.56 \\
(4.06) \\
\end{array}$ & $\begin{array}{r}* * 53.71 \\
(4.28) \\
\end{array}$ \\
\hline A_ENT(-1) & $\begin{array}{r}* * *-3.08 \\
(-6.41) \\
\end{array}$ & & & \\
\hline A_EMPL(-1) & & $\begin{array}{r}*-1.19 \\
(-1.89) \\
\end{array}$ & & \\
\hline A_TURN(-1) & & & $\begin{array}{r}* *-1.48 \\
(-3.01) \\
\end{array}$ & \\
\hline A_GVA(-1) & & & & $\begin{array}{r}* *-1.33 \\
(-2.16) \\
\end{array}$ \\
\hline UNEMPL(-1) & $\begin{array}{r}*-0.63 \\
(-1.65) \\
\end{array}$ & $\begin{array}{r}* * *-1.52 \\
(-2.89) \\
\end{array}$ & $\begin{array}{r}* *-1.27 \\
(-2.56) \\
\end{array}$ & $\begin{array}{r}* * *-1.46 \\
(-2.81) \\
\end{array}$ \\
\hline EXPORT(-1) & $\begin{array}{r}* * * 1.22 \\
(7.20) \\
\end{array}$ & $\begin{array}{r}* * * 1.38 \\
(3.97) \\
\end{array}$ & $\begin{array}{r}* * * 1.47 \\
(5.05) \\
\end{array}$ & $\begin{array}{r}* * * 1.44 \\
(4.21) \\
\end{array}$ \\
\hline POPUL(-1) & $\begin{array}{r}-0.54 \\
(-0.96) \\
\end{array}$ & $\begin{array}{r}-0.92 \\
(-1.04) \\
\end{array}$ & $\begin{array}{r}-0.92 \\
(-1.16) \\
\end{array}$ & $\begin{array}{r}-0.96 \\
(-1.11) \\
\end{array}$ \\
\hline Adjusted $\mathrm{R}^{2}$ & 0.81 & 0.57 & 0.63 & 0.58 \\
\hline Wald chi square & $* * * 111.77$ & $* * * 35.26$ & $* * * 46.47$ & $* * * 37.50$ \\
\hline Period & $2010-2018$ & $2010-2018$ & $2010-2018$ & $2010-2018$ \\
\hline Observations & 32 & 32 & 32 & 32 \\
\hline
\end{tabular}

Note: beta coefficients in front of parentheses, $\mathrm{z}$-values in parentheses; $*, * *, * * *$ denotes statistical significance at the level of $10 \%, 5 \%$ and $1 \%$, respectively

\section{Discussion}

In total, twelve regression models showed that agricultural activity negatively affected the region's contribution to the GDP. In other words, regions with higher agricultural activity contribute to the lesser extent to the GDP of the country. As the agriculture is one of the core industries in developing economies, some changes in the organization of agricultural activity in the Republic of Serbia have to be considered. Therefore, several improvements may be proposed. In general, there are two broad areas of improvements:

- enhancing the coordination and cooperation in agricultural sector in order to overcome the problem of fragmentation of production (many companies with relatively small production capacities);

- modernization of agricultural production and implementation of information technologies in order to improve efficiency of agricultural enterprises.

Coordination and cooperation in the agricultural sector should be enhanced both on horizontal and vertical basis. In this regard, horizontal cooperation between agricultural companies may increase their negotiating power. For instance, Volpentesta and Ammirato (2018) argue that innovative organizational models and clusters should be implemented in order to overcome the challenges that world-wide agrarian sector cope with. 
In addition, vertical coordination should improve the competitive position of the agrifood sector in the Republic of Serbia. Ideas on improvement of vertical coordination have a long tradition (Folkerts \& Koehorst, 1997) and are particularly important for developing countries (Kirsten \& Sartorius, 2002). Regarding agricultural enterprises in the Republic of Serbia, it is important to produce and export the products of higher processing stages as it enables agricultural enterprises to gain higher profit margin. In addition, exporting products of higher processing stages may increase overall profitability and competitiveness of the enterprises (Boganović \& Hadžić, 2018).

It may also be suggested to furtherly develop the concept of multifunctionality of agriculture (Casini et al., 2012; Lehmann et al., 2009), which also have an impact on sustainable development (Hediger \& Knickel, 2009). For instance, agricultural industry may be integrated with secondary sector's manufacturing companies as well as tertiary sector's tourism organizations (Garabinović, 2019). In addition, the development of the agrarian sector may be achieved through the integration with both the pre-farm and post-farm sectors.

Second group of improvements refers to the implementation of modern technologies in the agricultural enterprises. In this regard, agro-industrial enterprises should apply modern information technologies in production, since the application of these technologies and innovations, together with coordination between different levels of the agri-food sector play a significant role in improving their competitiveness (Boehlje et al., 2011; Streeter et al., 1991).

However, investments in modernization require additional funds (Andrei \& Darvasi, 2012). Popović et al. (2018) argue that agricultural enterprises should more rely on the agricultural loans, concluding that this segment is not developed enough in the Republic of Serbia. In addition, agricultural enterprises in the Republic of Serbia do not use corporate bonds to finance investments. Therefore, issuing bonds may be the attractive option, in particular for larger agricultural enterprises.

In particular, agricultural SMEs (as dominant players in the agricultural industry) should continuously innovate and introduce information and communication technologies into their businesses (Burke, 2010), in order to increase productivity and competitiveness at the national and international level. Bearing in mind that the export of agro-industrial products makes the basis of agricultural development, it is essential to raise the level of technological level of production, productivity and efficiency in this area (Vlahović et al., 2011).

Such improvements may increase the efficiency of agricultural companies and make the impact of agriculture on economic growth better. In addition, such improvements and state-supported macroeconomic environment should encourage private investments in agriculture and further development of agricultural enterprises. 


\section{Conclusions}

The paper examined the impact of agricultural enterprises on the economic growth of the Republic of Serbia in the period between 2010 and 2018. Considering important cross-regional differences in agricultural activity, the analysis was conducted at the NUTS 2 regional level. Activity of the agricultural enterprises in the region was measured by number of agricultural enterprises, number of employees in them, their turnover and gross value added.

The random-effects GLS regression showed that agricultural enterprises negatively impacted the economic growth of the country. In other words, the regions with higher activity of agricultural enterprises contributed to GDP of the country to the lesser extent. Therefore, there is enough evidence to reject the null hypothesis, and to accept the alternative hypothesis.

Research results are same regardless of the measure of activity of agricultural companies. In addition, results are robust to the changes of the sampling period and lagging the independent variables. In total, twelve regression models confirmed the statistically significant negative impact of agricultural sector on the economic growth. In particular, we found that the implementation of the Strategy for the Agriculture and Rural Development 2014-2024 did not considerably change the impact of agriculture on the economic growth. However, the full effects of this strategy should be considered only after the 2024 as a final year of the strategy. The paper covers only the half of the period of the strategy.

In this regard, some recommendations for the improvement of efficiency of agricultural enterprises and their impact on the economic growth of the country were proposed. First, a state-supported macroeconomic environment is needed with appropriate agricultural strategy and, in particular, support towards the micro enterprises and SMEs. On the other hand, it should be noted that agriculture is traditionally less capitalintensive industry and that some more capital-intensive industries (such as information technologies industry) ensure the faster economic growth of the countries.

Second, the efficiency of agricultural enterprises may be increased in many ways that can be placed into two broad areas: enhancing the coordination and cooperation among agricultural enterprises, and modernization of agricultural production and implementation of the information technologies. For instance, integration of agricultural enterprises into clusters should enable the enterprises to overcome the problem of fragmentation of production. On the other hand, continuous innovation is considered as a path for agricultural enterprises development both in developed and developing countries.

In addition, agricultural enterprises should overcome the lack of financing sources problems. Micro and small agricultural enterprises should have the better access to the agricultural loans, while medium and large agricultural enterprises should consider the corporate bonds issuance. 
The paper contributes to the research on the development of agricultural companies in the Republic of Serbia as a possible path for enhancing the economic growth of the country. In particular, the paper sheds the light on the efficiency of the agricultural companies and gives the recommendations for the improvement of their efficiency. An important feature of the paper is that it covers all agricultural companies regardless of their size, unlike many previous research covering only SMEs.

The authors believe that many interest groups may benefit from the research results. Macroeconomics policymakers and Ministry of Agriculture, Forestry and Water Management may use the research results when designing strategy of the economic development of the country and deciding on the ways of the development of the agricultural industry, respectively. In particular, research results from this paper should be useful when deciding on state-support programs in the agricultural sector. On the other hand, owners and managers of the agricultural companies may find useful recommendations for improving the efficiency of their companies.

The research results should be used in the light of some limitations. The main limitation of the research may be found in the relatively short sampling period and relatively small number of regions. In this regard, future research should cover other transition countries in order to compare research results. In addition, future regional analysis may focus only on the SMEs in order to examine only their impact on the economic growth. It would also be interesting to conduct the analysis after the final year of the Strategy for the Agricultural and Rural Development 2014-2024.

\section{Acknowledgements}

The paper is a part of the research done within the project number III 47005, financed by the Ministry of Education, Science and Technological Development of the Republic of Serbia.

\section{Conflict of interests}

The authors declare no conflict of interest.

\section{References}

1. Andrei, J. V., \& Darvasi, D. (2012). Perspectives and challenges in financing the new Common Agricultural Policy, a new paradigm. Journal of Food, Agriculture \& Environment, 10(1 part 2), 904-907.

2. Andrei, J. V., Mieila, M., \& Panait, M. (2017). The impact and determinants of the energy paradigm on economic growth in European Union. PloS one, 12(3), e0173282. doi:10.1371/journal.pone.0173282

3. Aničić, D., Nestorović, O., Simić, N., \& Miletić, S. (2019). The perspectives of sustainable development of Serbia's agriculture in globalized environment. Economics of Agriculture, 66(1), 221-235. doi: 10.5937/ekoPolj1901221A 
4. Aničić, J., Vukotić, S., \& Krstić, S. (2016). The strategic aspects and results of agriculture development in Serbia in the transition period. Economics of Agriculture, 63(1), 175-187. doi: 10.5937/ekoPolj1601175A

5. Avermaete, T., Viaene, J., Morgan, E. J., \& Crawford, N. (2003). Determinants of innovation in small food firms. European Journal of Innovation Management, 6(1), 8-17. doi: 10.1108/14601060310459163

6. Batterink, M.H., Wubben, E.,Klerkx,L.,\&Omta,S.(2010). Orchestrating innovation networks: The case of innovation brokers in the agri-food sector. Entrepreneurship \& Regional Development, 22(1), 47-76. doi: 10.1080/08985620903220512

7. Boehlje, M., Roucan-Kane, M., \& Bröring, S. (2011). Future agribusiness challenges: Strategic uncertainty, innovation and structural change. International Food and Agribusiness Management Review, 14(5), 53-82.

8. Bogdanović, S, \& Hadžić, M. (2018). Encouraging export of agricultural products of higher processing stages. Ekonomija-Teorija i praksa, 11(1), 35-51. [in Serbian: Богдановић, С., \& Хаџић, М. (2018). Подстицање извоза пољопривредних производа виших фаза прераде].

9. Bošković, G., \& Kostadinović, I. (2011). SMEs clusters - the key to economic development. Škola biznisa, 4, 54-68. [in Serbian: Бошковић, Г., \& Костадиновић, И. (2011). Кластери малих и средњих предузећа - кључ економског развоја].

10. Bubić, J., \& Hajnrih, J. (2012). The analyses business performances of agricultural enterprises in Vojvodina during the current crisis. Economics of Agriculture, 59(2), 183-194.

11. Burke, K. (2010). The impact of Internet and ICT use among SME agribusiness growers and producers. Journal of Small Business \& Entrepreneurship, 23(2), 173-194. doi:10.1080/08276331.2010.10593480

12. Casini, L., Contini, C., \& Romano, C. (2012). Paths to developing multifunctional agriculture: insights for rural development policies. International Journal of Agricultural Resources, Governance and Ecology, 9(3-4), 185-203. doi: 10.1504/ IJARGE.2012.050347

13. Drăgoi, M. C., Andrei, J. V., Mieilă, M., Panait, M., Dobrotă, C. E., \& Lădaru, R. G. (2018). Food safety and security in Romania - An econometric analysis in the context of national agricultural paradigm transformation. Amfiteatru Economic, 20(47), 134-150. doi:10.24818/ea/2018/47/134

14. Folkerts, H., \& Koehorst, H. (1997). Challenges in international food supply chains: Vertical co-ordination in the European agribusiness and food industries. Supply Chain Management, 2(1), 11-14. doi: 10.1108/13598549710156312

15. Garabinović, D. (2019). Online marketing promotion of local tourism organizations: The analysis of the situation in Moravica administrative district. Menadžment $u$ hotelijerstvu i turizmu - Hotel and Tourism Management, 7(1), 71-81. doi:10.5937/ menhottur1901071g 
16. Hediger,W.,\&Knickel,K.(2009).Multifunctionality and sustainabilityofagriculture and rural areas: A welfare economics perspective. Journal of Environmental Policy \& Planning, 11(4), 291-313. doi: 10.1080/1523908090341245

17. King, R., Boehlje, M., Cook, M., \& Sonka, S. T. (2010). Agribusiness economics and management. American Journal of Agricultural Economics, 92(2), 554-570. doi:10.1093/ajae/aaq009

18. Kirsten, J., \& Sartorius, K. (2002). Linking agribusiness and small-scale farmers in developing countries: Is there a new role for contract farming? Development Southern Africa, 19(4), 503-529. doi: 10.1080/0376835022000019428

19. Knudson, W., Wysocki, A., Champagne, J., \& Peterson, H. C. (2004). Entrepreneurship and innovation in the agri-food system. American Journal of AgriculturalEconomics, 86(5), 1330-1336.doi:10.1111/j.0002-9092.2004.00685.x

20. Lehmann, P., Schleyer, C., Wätzold, F., \& Wüstemann, H. (2009). Promoting multifunctionality of agriculture: An economic analysis of new approaches in Germany. Journal of Environmental Policy \& Planning, 11(4), 315-332. doi: 10.1080/15239080903033879

21. Lowe, T., \& Preckel, P. (2004). Decision technologies for agribusiness problems: A brief review of selected literature and a call for research. Manufacturing \& Service Operations Management, 6(3), 201-208. doi:10.1287/msom.1040.0051

22. Maletić, R., \& Ćeranić, S. (2010). Small and medium enterprises as development factor of agribusiness in Republic of Serbia. Applied Studies in Agribusiness and Commerce, 4(3-4), 45-50. doi: 10.22004/ag.econ.91130

23. Maletić, R., Popović, B., \& Paunović, T. (2014). Regional aspect of agribusiness SMEs development in Serbia - opportunity to reduce unemployment. Teme, 38(4), 1445-1456.

24. Mijačić, D., \& Paunović, B. (2011). Regional disparities in Serbia. Ekonomika preduzé́a, 59(7-8), 379-389. doi: 10.5937/ekopre1108379M

25. Milanović, M., Stevanović, S., \& Vićentijević, D. (2013). Competitiveness and potentials of Serbia's agrarian foreign trade. Teme, 37(1), 297-317. [in Serbian: Милановић, М., Стевановић, С., \& Вићентијевић, Д. (2013). Конкурентност и потенцијали аграрне спољне трговине Србије].

26. Pantić, O. (2015). The role of the SMEs sector in structural changes in agriculture in the Republic of Serbia. In: Strukturne promene u Srbiji-dosadašnji rezultati $i$ perspektive (331-345). Beograd: Institut ekonomskih nauka. [in Serbian: Пантић, О. (2015). Улога сектора МСП у структурним променама пољопривреде Републике Србије].

27. Petrović, P., \& Vuković, D. (2016). Financial sources of small and medium enterprises for agribusiness and eco-tourism in Serbia. Economics of Agriculture, 63(4), 1433-1444. doi:10.5937/ekopolj1604433p 
28. Popović, B. (2009). Contribution of small and medium sized enterprises in development of agribusiness of Serbian republic. Journal of Agricultural Sciences, $54(1), 62-79$.

29. Popović, S., Janković, I., \& Stojanović, Ž. (2018). The importance of bank credits for agricultural financing in Serbia. Economics of Agriculture, 65(1), 65-80. doi: 10.5937/ekopolj1801065p.

30. Ristić, L. (2013). Strategic management of sustainable rural development in the Republic of Serbia. Ekonomski horizonti, 15(3), 229-243. [in Serbian: Ристић, Л. (2013). Стратегијско управљање одрживим руралним развојем у Републици Србији].

31. Sedlak, O., Jovin, S., Pejanović, R., Ćirić, Z., \& Eremić Đođić, J. (2016). Access to finance for micro, small and medium business units in Serbian agribusiness. Economics of Agriculture, 63(4), 1219-1235. doi: 10.5937/ekoPolj1604219S

32. Statistical Office of Republic of Serbia. (2010-2018). Enterprises in the Republic of Serbia, by size, for years 2010-2018. Belgrade: SORS. [in Serbian: Републички завод за статистику. (2010-2018). Предузећа у Републици Србији, према величини, за године 2010-2018]. Retrieved from https://www.stat.gov.rs/ publikacije/, for years 2010-2018 (May 14, 2020).

33. Streeter, D., Sonka, S., \& Hudson, M. (1991). Information technology, coordination, and competitiveness in the food and agribusiness sector. American Journal of Agricultural Economics, 73(5), 1465-1471. doi: 10.2307/1242403

34. Tomašević, S., Jović, Z., \& Vlaović-Begović, S. (2019). The impact of enterprise size on profitabiliy of agricultural enterprises in the Republic of Serbia. Journal of Agricultural Sciences, 64(3), 293-302. doi: 10.2298/JAS1903293T

35. Vlahović, B., Tomić, D., \& Kuzman, B. (2011). External trade of agro-industrial products of the Republic of Serbia and Croatia. Tranzicija: Časopis za ekonomiju i politiku tranzicije, 13(27), 120-127. [in Serbian: Влаховић, Б., Томић, Д., \& Кузман, Б. (2011). Спољнотрговинска размена агроиндустријских производа Републике Србије и Хрватске].

36. Volpentesta A.P., \& Ammirato S. (2008). Networking Agrifood SMEs and Consumer Groups in Local Agribusiness. In: Camarinha-Matos L.M., Picard W. (eds). Pervasive Collaborative Networks. PRO-VE 2008. IFIP-The International Federation for Information Processing, vol 283. (p. 33-40) Springer, Boston, MA. doi: 10.1007/978-0-387-84837-2_4

37. Vržina, S., \& Dimitrijević, M. (2020). Determinants of profitability of the agricultural sector of vojvodina: The role of corporate income tax. The European Journal of Applied Economics, 17(1), 1-19. doi: 10.5937/ejae17-21368 